\title{
CUSTOMER VALUE IN USING ELECTRONIC BANKING \\ (WHAT THE MILLENNIAL GENERATION SAY ABOUT “CUSTOMER VALUE” OF USING ELECTRONIC BANKING)
}

\author{
Endang. PB \\ ebromoyudho@gmail.com \\ Ali.Masjono \\ Ali.masjonomuchtar@akuntansi.pnj.ac.id \\ Politeknik Negeri Jakarta
}

\begin{abstract}
The changing from human services to electronic services affects the millennial generation activities. Electronic banking services give the rise customer value, and electronic banking provided by a reputation bank increase the pride of using the services. Banks services without human's interaction can increase customer value or benefits. These conclusion raise from the survey of 216 millennial respondents, age between 20 to 35 years old who use gadget for daily activities and interaction with the bank.
\end{abstract}

Keywords: Electronic Banking, Customer Value, Cost of Service, and Technology Advancement, Pride

\begin{abstract}
ABSTRAK
Perubahan bentuk layanan perbankan dari berbasis kepada layanan yang dilakukan oleh manusia kepada layanan berbasis mesin, telah memberikan dampak kepada generasi milenial. Jasa layanan elektronic banking telah memberikan nilai atau makna (customer Value) kepada para pengguna jasa layanan elektronik banking yang disediakan oleh perbankan nasional bereputasi. Layanan electronic banking telah meningkatkan kebanggaan menggunakan layanan tersebut, terutama untuk para generasi milenial yang di survei sebanyak 216 nasabah dan berumur antar 20-35 tahun.
\end{abstract}

Keywords: Electronic Banking, Customer Value, Cost of Service, and Technology Advancement, Pride

\section{INTRODUCTION}

Background of Study

Banking Industry is the most affected and most quickly adapts to technological progress. The consequence of changes in technology in the banking industry is a change in service that affects customer satisfaction. Is a satisfied customer will certainly get benefits? The problem is whether customers (millennial generation as target of the survey) are really get the value (benefits) of using Electronic Banking. The questions that need answer are whether the machine service really can increase the value or benefit from using electronic banking services.
A prominent phenomenon in banking services is electronic-banking services replace all manual system. Electronic Banking is the development of bank products and services that have traditionally been marketed/used by all banks. Information Communication Technology (ICT) has given rise to various developments in bank products and services, among others, known as eBanking services. The types of e-Banking services include Automatic Teller Machine (ATM), Bank Internet, mobile banking, Phone Banking, T-Cash (NFC).

With the progress of the ICT, the customer's existence is uncontrollable because the customers moves according to their wishes and will depends on the customer's situation/position at a certain 
time. From here, this is an indication that the customers want to be pleased wherever the customer are.

Of the various technology change, affect the banking services, these also change customer behavior. The changing behavior form human interaction to machine interaction.

The existence of e banking has brought changes in determining customer value. In almost all types of companies, customer value has become a reference (index or barometer) for the development of a product or services produced by the organization. Measuring Customer value by the quality of goods and services that customers feel and consume are important.

\section{Problems statement}

The phenomena described in the background can indicate there is a problem that are happening in the banking industry, namely changes in attitudes, perceptions of banking electronic services. Customers get the benefit or value of e-banking services and change the perception of what is happening to the customer, and whether the electronic based services really give big benefits.

\section{Objectives}

The changing approach of bank services from human interaction to machine interaction affect human behavior, thus main objective is to determine and analysis the benefit or value from using electronic

\section{LITERATURE REVIEW Customers Value.}

Customer value is, philosophically, about understanding human and business purposes and adoption and transaction processes. (Paananen. Marko Seppänen. (2013). Determining and managing customer value is an important strategy in a company, through customer value a company can choose target markets and get, keep, and grow customers through creating, delivering, and communicating superior customer value (Kotler, 2001).
Likewise in the banking world and in-line with the development of ICTs, has brought about a change in views on customer value. When using the internet-banking customer hopes to get benefits, the bank as a service provider, hopes to fulfill this hope to be able to satisfy the customer and not move to another bank provider.

Customer value is the level of perceived quality of e-banking relative to the price paid by customers compared to competitors. (Depending on the customer's income and budget). So a customer will give a high value if the benefits of the service are greater than the sacrifice given. (Fornell, 1996 et.al). Thus the question is what benefits do customers receive with ebanking? How much is the sacrifice, what customers do to get e-banking services, all are a benchmark for customers to provide a quality level of e-banking services.

In the marketing world, Customer Value consists of the number of benefits that customers are compared to the costs (costs) incurred by the customer. Thus, the customer value can explain why a customer must use e-banking services and differentiate them from the same services as competitors. Getting attention of customers and being willing to use ebanking services will increase market share and customer satisfaction (Wikipedia,2017)

The great benefits that customers receive will affect the level of customer retention (the desire to buy back or reuse services or goods that have been purchased) Liu, A. H. (1998). A research indicates that it is very important to understand repurchase intention. Further said that there are three key factors that become antecedent; repurchase intension; customer value, customer satisfaction and perceived switching costs.

The service is an activity or workmanship that is offered by one party to another party where the service is intangible and there is no transfer of ownership. In its activities, it may be bound to tangible products. Kotler, P. Keller,KL. (2012). 
Information delivery is an entity that is greatly affected by the acceleration of technology development. Services that have been conveyed to customers only occur if they have met with customers with technology or without having to meet directly with customers. Banks in this case are very affected by the existence of changing technology. Looking at the current information technology, bank services almost entirely relate to various other services from non-bank companies offered to their respective customers.

The use of technology in e banking is necessary for current situation; the process behind the technology is unknown to customers. Simply put, in the customer's perspective; if a customer deposits money, the money (balance) in the account will increase. The process that occurs and done by the technology, the customer does not know and does not understand the process, so it is not uncommon for the customer to complain because of the lack of synchronization in the way of thinking of the customer of processing in the bank. Then the bank must provide a high level of value or benefits to reassure that the e banking services are the trustable.

\section{METHODS}

This is a simple survey using an instrument applying a the Likert Scale of a 5 point scale that offers a range of answer options, from one extreme attitude to another. Data collection used Google form documentation that was distributed to respondents. Data calculation based on the number of answers to each question.

\section{DISCUSSION \\ Respondent's Profile}

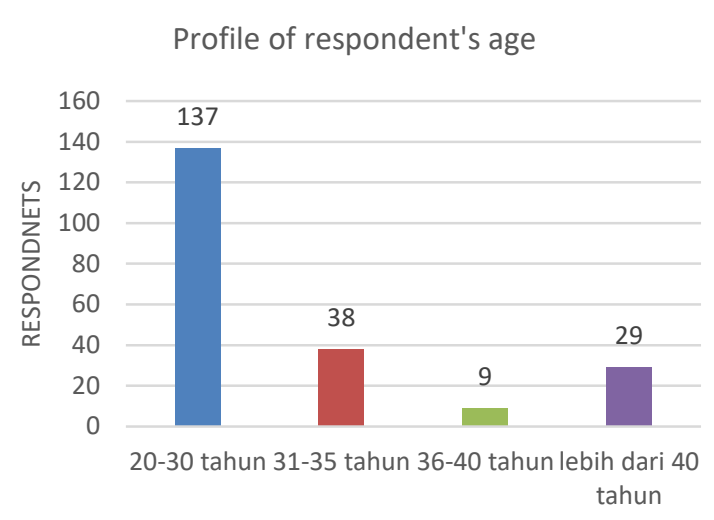

Source: Primary data

*tahun= year old

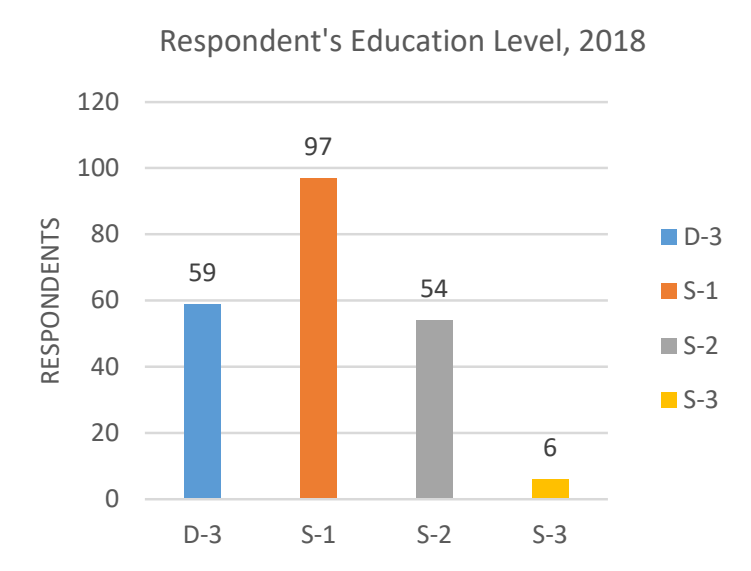

Source: Primary data

*D-3=Diploma

S-1= Bachelor

S-2=Master Degree

$\mathrm{S}-3=$ Doctor or PhD Degree

RESPONDENT'S TYPE OF OCCUPATION, 2018

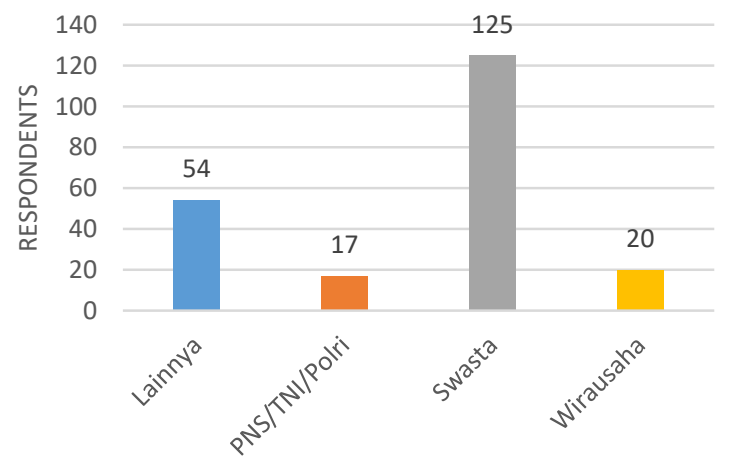

Source: Primary data

*PNS/TNI/Polri= Civil Servant, include

Army and Police.

Swasta $=$ non-government employee

Wirausaha=Entrepreneur

Lainnya=Other 
Millennial generation for now is between 20-35 years old, this generation is currently enjoying electronic banking services and life in Jakarta and its suburb area. This research makes this generation as respondents. The main reason for choosing this group of respondents was that they were an age group who since birth expose to technological advances. Another reason is that there has been a change in attitude towards customer value, if in the past, electronic banking era, banking services were carried out by humans, so customer value was created because of the influence of interaction with bank employees. This generation has been accustomed to use applications to interact with fellow friends, to do transaction online and for various other purposes

\section{Respondents get a value or benefit when doing transaction in electronic banking, 2018}

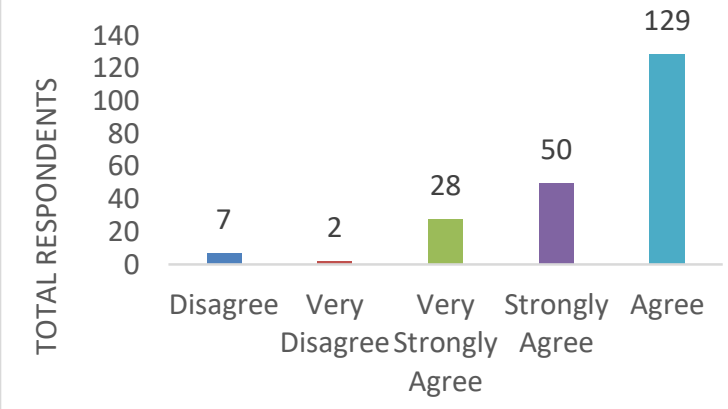

\section{Source: Primary data}

Type of electronic Banking used by Customers, 2018

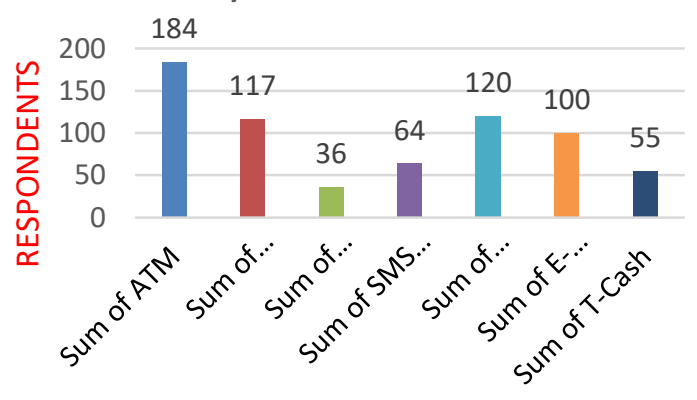

\section{Source: Primary data}

*ATM, Internet Banking, Phone Banking, SMS Banking, Mobile Banking, E-money, T-Cash
Some respondent do not use ATM any more, from 216 respondents, there are 32 respondent do not use ATM, from data above graphic can be seen that they are move to use of Mobile banking, where mobile banking in the second position among other.

\section{Respondents get a value or benefit when using electronic banking 2018}

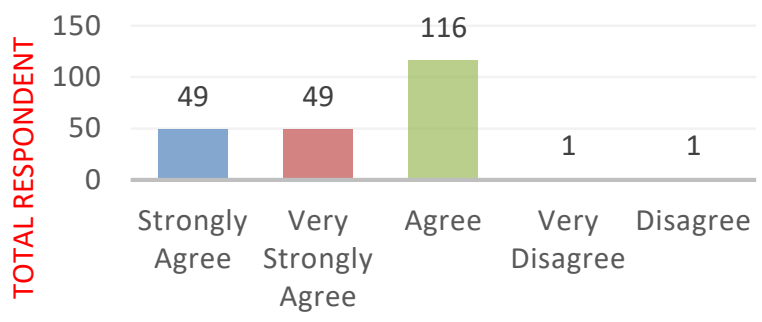

\section{Source: Primary data}

Most respondent agree that they have got the benefit or value every time they doing transaction (transfer withdraw, ect) using electronic banking. If this respondents grouped into two big group, such as agree and disagree, it can be imply that the electronic transaction will become the basic need to this respondent

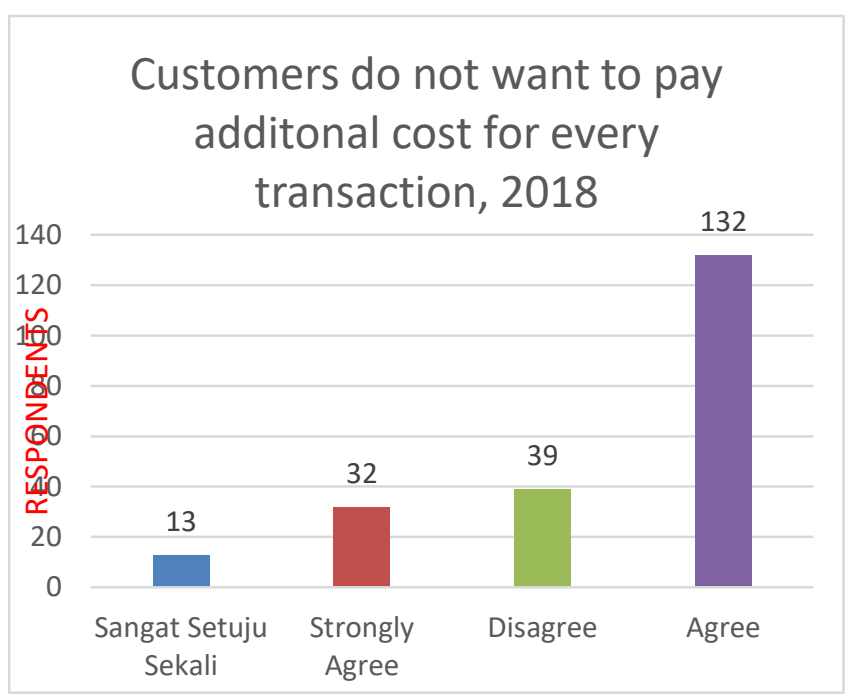

\section{Source: Primary data}

Similar situation, which describe above, cost of using electronic banking is suitable with benefit they got. Mostly respondents agree with this, few of them are strongly agree and only two respondent with very strongly agree. This means that 
young generation agree with the current cost of transaction and have the benefit of the cost they have been spent. Furthermore, this is an indication that electronic banking will be especially mobile banking will get the main application in the future. According to the respondent profile, it has been started already the shifting from using ATM to Mobile banking

Direcly or indireclty, customer proud of using electronic banking because of the service provider reputation, 2018.

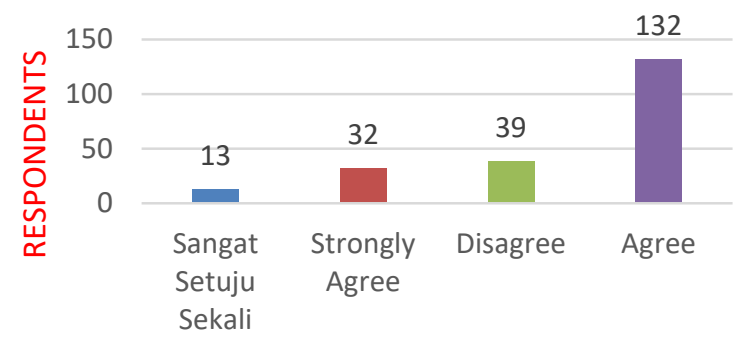

\section{Source: Primary data}

Sangat setuju sekali=very strong Agree

Electronic banking has become a lifestyle because it can be used anytime, anywhere, without restriction. The pride felt by the respondent for the use of electronic banking is largely determined by the bank that provides services. Most of the respondents agree that the electronic banking they currently have is due to your element of bank reputation.

The value obtained by the respondent (bank customers) is the result of interaction with the bank through electronic banking. More than $50 \%$ of customers or respondents said that interactions and transactions through electronic banking has increased the benefits of using electronic banking.

Costs that must be borne to get electronic services are in accordance with the value obtained. This indicates that the cost (monthly charge) related to the use of electronic banking has met the wishes of the customer. On the contrary, almost all respondents said that additional fees in making transaction is a burdensome, for example additional fees if making a money transfer.

Customer value or benefits obtained by bank's customers have so far given credit to the technological advantages possessed by banks (service providers). This is evidenced by the results of the survey which said that there was a certain pride in having electronic banking from reputable banks, more than $50 \%$ of respondents said they agreed. Besides the bank's reputation as an electronic banking service provider, pride is also caused by the value or benefits of using electronic banking. These facts indicate that the value or benefit and reputation of the bank increases the pride of using electronic banking.

\section{CONCLUSION}

Electronic banking services give rise the customer value, more than $50 \%$ respondents prove this statement and electronic banking provided by a reputation bank increase the pride of using the services, this is also supported by the respondents. Banks services without human's interaction can increase customer value or benefits. Most of respondents agree on this. These conclusion raise from a survey of 216 millennial respondents, age between 20 to 35 years old and use gadget for daily activities include interaction with the bank.

\section{REFERENCES}

Fornell, C., Johnson, M. D., Anderson, E. W., Cha, J., \& Everitt Bryant, B. (1996). Growing the trust relationship [Electronic version]. Journal of Marketing, 60(4), 7-18. Retrieved [insert date], from Cornell University, School of Hospitality Administration site: http://scholarship.sha.cornell.edu/art icles/431/

Kotler, P. Keller,KL. (2012). Marketing Management. New Jersey; Pearson Education. Inc. March-April. 56-69. 
Wikipedia,FreeEncyclopediaOnline,(2017 ).https://en.wikipedia.org/wiki/Cust omer_value_proposition. accessed 20 Jan 2017 at 16.52 WIB.

Liu, A. H. (1998). Examining the role of customer value, customer satisfaction, and perceived switching costs: A model of repurchase intention for business-to-business services (Order No. 9835214). Available from ProQuest Dissertations \& Theses Global: The Humanities and Social Sciences Collection. (304444503). Retrieved from

https://search.proquest.com/docvie w/304444503? accountid=25704

Gryc, Wojciech (2012) "Four Dimension of customer Value" https://canopylabs.com/blog/thefour-dimensions-of-customer-value.

Kotler, Philip. (2000), Marketing Management, the Millenium Edition Upper Saddle River, N. J: PrenticeHall, International Inc

Paananen. Marko Seppänen. (2013)" Reviewing customer value literature: Center for Innovation and Technology Research (CITER), Finland: OmniaSciece Tampere University of Technology" IC, 2013 - 9 ( 3): 389-xx - Online ISSN: 1697-9818 - Print ISSN: 2014-3214 http://dx.doi.org/10.3926/ic. 389

\section{FURTHER RESEARCH}

The weaknesses of this survey the method of analysis the result is very simple, therefore it is possible to analyses using other method and combine with other survey.

\section{ACKNOWLEDGMENTS}

Thank you for P3M Politeknik Negeri Jakarta for supporting this survey and for my colleagues who help in conducting the survey. Without your help, this survey cannot be finished. 